\title{
Community care of the elderly: some problems viewed from one inner city area
}

\author{
Melanie Abas and Marisa Silverman
}

\begin{abstract}
Problems linked to community care of the elderly subsequent to recent NHS changes are reviewed in an inner city London area. Concem remains that financial and administrattve contraints will take precedence over the initiction of needis-led packages of care. Joint health and social service agreements are necessary to establish, monitor and improve standards, and to ensure that adequate data are collected so that problems in arrangements can be highlighted.
\end{abstract}

Recent National Health Service (NHS) changes (House of Commons, 1990) demand that local authorities inform the public of what assistance may be available to them; they are also held to carry out assessments and implement and monitor packages of care (for a review see Thornicroft, 1994). Funds for residential and nursing home care, previously a 'bottomless pit' of resources held by the Department of Social Security, have been handed over to local authorities. Although theoretically they may be used more flexdbly, e.g. in buying services to keep people at home, it means they are now cash limited. While the shift in balance from state to individual responsibility for funding long-term care has become increasingly manifest, new guidelines (Department of Health, 1995) charge health authorities with setting criteria for those few who will be eligible for NHS continuing care, and with developing local purchasing policies with respect to that care.

\section{Problems for the elderly}

Three years since the implementation of the new arrangements for community care, discrepancies have been reported across the country and between disciplines. Shire councils in South West England announced in 1994 that their budgets were exhausted only three-quarters of the way through the financial year and general practitioners (GPs) in the Wye Valley described battling with "severely rationed services" for elderly people in the community (Galloway, 1994). However, physicians from West London (Ajayi et al, 1995) found that, since the changes, physically sick older people were more likely to be discharged quickly and sent back to their own homes. Experience from Edinburgh has been that the proportion of elderly awaiting placement there has fallen more rapidly since 1993 , a major factor being faster placement into private nursing homes (Namardan et al, 1995).

In East Lambeth, South London, an area with composite poverty indices higher than the inner London average, a number of issues are emerging. These are discussed below.

Delays in placement of the elderly mentally ill from in-patient psychiatric wards

While local audit has revealed some delay, relative to locally agreed target time-scales, in carrying out needs assessments, funding has in nearly al cases been forthcoming and rapidly agreed. However the lack of nursing homes has led to significant delays in identifying appropriate placements. Although some innovations have emerged since 1993, such as an increase in respite places, and new home bathing and home alarm services, creative models of care provision are required, especially for those with special needs. Nursing home, residential, special housing, respite, domiciliary and day-care resources are desperately needed for such groups as ethnic minority elders, younger patients with dementia. frail elders and older people with persistent active mental illness. Consultation with users has demonstrated an increasing demand for homebased packages as an alternative to residential care.

\section{Threat of under-funding}

The standard spending assessment for each borough was weighted on the basis of the existing level of placements available. For areas with small numbers of residential and nursing homes, the cost of placing people out of the borough was thus ignored although, for Lambeth, data on past placement expenditure was used to support the 
case for a greater allocation for older people than had originally been suggested within the local budget.

Given that the number of people over 65 will decrease in Lambeth over the next decade (Lambeth, Southwark \& Lewisham Health Commission, 1994), and that elderly people will continue to be 'exported out' to residential homes in surrounding suburbs, funding may decrease, despite: a) the extreme levels of mental illness in such inner city areas, compounded by the import of people with severe mental health problems due to the availability of lodging house places; b) the projected urban growth of those aged over 85 , which will result in an increase in the numbers of the most frail and of those with dementia; and c) the finding that almost half of all pensioners in Lambeth live alone and a third either have no bathroom or share facilities with another household, or have no central heating (London Borough of Lambeth, 1994).

Delay in carrying out assessments for elderly people living in the community

Given the limitations on social workers' time and the length of time that assessments can take, there is a need to reduce the unnecessary complexity and improve the uniformity of the assessment procedure being followed (Hamid et al. 1995). More community social workers for older adults are required, together with a reduction in the bureaucracy involved in completing an assessment, especially when the elderly person may have only one or two specific needs.

\section{Lack of monitoring of private provision}

Demand for residential care is predicted to drop slowly, but it is possible that standards will fall further in those residential homes that are already less popular. The lack of clear joint agreements, and of resources, to audit outcome for elderly people being placed in residential care means that results of placement are often not avallable. This is complicated by the siting of so many clients outside their original district, hence these are lost to follow-up and the team who placed them is unlikely to recetve feedback if problems ensue.

In many cases, home care is contracted out to the independent sector. Private agencies tend to have a high staff turnover, possibly leading to the disruption of care plans, unless these are specified, and of client trust. The neighbouring borough. Southwark, has identified the need to develop an approved list of private domiciliary care providers to better regulate social service purchasing (Southwark Council, 1995). Joint working with the Health Service is required to establish standards and agree monitoring and the identification of unmet needs.

\section{Implications for general practitioners}

More consultation is required to improve joint GP/social service working in such areas as identifying those elderly patients who might benefit from a needs assessment, in providing medical reports for such assessments, in handing over confidential information, and in GP negotiation for, and purchasing of, packages of care. The over-75 Health Check is one obvious point at which those identified as potentially in need could be referred to the local authority, although GPs may prioritise more 'visible' elderly patients with neurotic disorders rather than the "quietly cognitively impaired'.

\section{New emphasis on NHS responsibilities for continuing health care}

Many long-stay beds have been lost with an increasing emphasis on patients facing meanstested care in the community. While those assessed as not needing NHS care are to be discharged, if necessary against their will following the planned new appeal procedure, some will rightly still be eligible (Department of Health, 1995). By the end of September 1995, health authorities must have drafted local policies and eligibility criteria for continuing health care. Establishing such criteria is an exacting task and defending them likely to pose difficult questions (Pearson \& Wistow, 1995). Distinguishing whether the patient has, for example, 1) "the need for frequent, not easily predictable interventions" requiring the regular supervision of an NHS member of the multidisciplinary team, or 2) the "need for regular access" to specialist medical, nursing or other community health services, is not easy. Yet patients in the former category will be eligible for continuing in-patient health care and those in the latter will not. Criteria for dementia will be more complex to set than, for example, for physical illnesses. Pressure may build up against admissions, e.g. for NHS respite care, if patients do not strictly meet eligibility criteria or if there is a fear that discharge of such patients "let in" to the NHS may subsequently be opposed by relatives. Although the guidance is to be welcomed in stating NHS commitment to continuing care, and thus in drawing purchasers' attention to their responsibilities, no new funding has been provided. In the absence of creative local initiatives, a return to block contracts for long-term beds can be predicted, with images of the old substandard facilities for the elderly mentally 111. Existing domiciliary, day care and other health 
support must be defended if the role of informal carers is not to be further undermined.

\section{Conclusions}

The principles embodied within the new legislation give a framework to negotiate appropriate services for patients and make social workers accountable for care management. However, financial and administrative constraints could, among other problems, take precedence over the emphasis of creating individual, needs-led packages of care. Information will be vital and non-complex ways of collecting this should be incorporated into computerised information systems. Audit of placements, of satisfaction with care packages, and of outcome for patients and carers must be carried out, the latter using such scales as Health of the Nation Outcome Scales (Royal College of Psychiatrists, 1994), although the latter may benefit from modification in this context. A consensus approach to needs assessment (Holloway, 1994) is urgently required and a standardised technique must be developed which could be used by a variety of social and health care staff (Hamid et al, 1995). Joint agreements will be crucial to set standards, agree monitoring and identification of unmet need and ensure that adequate data are being collected, so that shortcomings in arrangements and in funding can be highlighted.

\section{References}

Ajay, V., Miskelly, F. G. \& Walton, I. G. (1995) The NHS and Community Care Act 1990: is it a success for elderly people? Brittsh Medical Journal, 310, 439.
DEPARTMENT OF HEALTH (1995) NHS Responsibulities for Meeting Continuing Health Care Needs. (HSG (1995) 8). London: Department of Health.

Galloway, M. (1994) Crisis is forecast in care of elderly. Hospital Doctor, 29 September, 3.

HAMm, W. A., HownRD, R. \& SIIVERAn, M. (1995) Needs assessment in old age psychiatry - a need for standardisation. International Journal of Geriatric Psychiatry, 10, 533-540.

HoLLWAY, F. (1994) Need in community psychiatry: a consensus is required. Psychiatric Bullettr, 18, 321-323.

HOUSE OF COMmons (1990) The National Health Service and Community Care Act. London: HMSO.

LAMBETH, SOUTHWARK AND LEWISHAM HEALTH COMMISSION (1994) With Need in Mind: Summary of our 5-Year Strategy for Mental Health Services in South East London. London: Lambeth. Southwark and Lewisham Health Commission.

LONDON BOROUGH OF LAMBETH (1994) Community Care Plan for Lambeth. London: London Borough of Lambeth Lambeth. Southwark and Lewisham Health Commission.

Namdaran, F., Sherval, J. \& Burl, M. (1995) Elderly people and the 1990 Act. Brttish Medical Joumal, S10, 1606.

PEARSON, M. \& Wistow, G. (1995) The boundary between health care and social care. Brttsh Medical Joumal, $\mathbf{3 1 1}$. 208-209.

Royal Coluege of PSychIATRISTs (1994) Health of the Nation Outcome Scales. London: Royal College of Psychiatrists. College Research Unit.

SOUTHWARK COUNCIL (1995) Community Care Plan. London: Southwark Councll.

THORNICROFT, G. (1994) The NHS and Community Care Act. 1990. Psychlatric Bulletin, 18, 13-17.

* Melanie Abas, Lecturer, Section of Old Age, Institute of Psychiatry, London; and Marisa Silverman, Consultant Psychiatrist, Bethlem \& Maudsley NHS Trust, London

"Correspondence: Dr M. Abas, Section of Old Age, Institute of Psychiatry, London SE5 8AF 